\title{
Large Cell Medulloblastoma
}

National Cancer Institute

\section{Source}

National Cancer Institute. Large Cell Medulloblastoma. NCI Thesaurus. Code C6904.

A medulloblastoma composed of large cells with prominent nucleoli and a larger amount of cytoplasm in contrast with the cells of the classic medulloblastoma. 